\title{
Radical Returns in an Age of Revolutions
}

Le retour des radicaux à l'époque des révolutions

\section{Gordon Pentland}

\section{(2) OpenEdition}

1 Journals

\section{Electronic version}

URL: https://journals.openedition.org/etudesecossaises/222

DOI: 10.4000/etudesecossaises.222

ISSN: 1969-6337

\section{Publisher}

UGA Éditions/Université Grenoble Alpes

\section{Printed version}

Date of publication: 30 September 2010

Number of pages: 91-102

ISBN: 978-2-84310-173-1

ISSN: 1240-1439

\section{Electronic reference}

Gordon Pentland, "Radical Returns in an Age of Revolutions", Études écossaises [Online], 13 | 2010, Online since 30 September 2011, connection on 15 April 2023. URL: http://journals.openedition.org/ etudesecossaises/222 ; DOI: https://doi.org/10.4000/etudesecossaises.222

All rights reserved 


\section{Radical Returns in an Age of Revolutions}

In 1795, James Kennedy, a Paisley weaver and Assistant Secretary to the British Convention held in Edinburgh in 1793-94, published a collection of verse entitled Treason! Or Not Treason! Alias the Weavers Budget. Poems such as "Common Sense" and "Swinish Gruntings" and dedications to "The Majesty of the People" bore the unmistakable imprint of Painite ideology and of the intense debate surrounding the French Revolution. Kennedy also wrote consciously from the authorial perspective of a "Scotch Exile" and provided a prefatory stanza for the reader:

Chas'd from my calling to this hackney'd trade,

By persecution a poor Poet made-

Yet favour court not - scribble not for fame;

To blast Oppressors is my only aim.

With pain I started from a private life;

In sorrow left by Children and my Wife!

But though fair Freedom's foes have turn'd me out,

At every resting place I'll wheel about,

And charge the Villains!

Kennedy was not, however, enduring his exile at the penal colony of Botany Bay nor even "across the water" in Europe or North America. He was, in fact, in London, having fled Edinburgh on the discovery of the Pike Plot in 1794. In London he seems to have become part of a small knot of Scottish émigrés orbiting round the radical publisher, Daniel Isaac Eaton (Harris, 2008, pp. 104-5). What Kennedy's versifying does indicate is the centrality of ideas of "exile" to the language and symbolism of popular politics.

There are a number of very good reasons as to why exile was such a prominent theme in radical movements and an obvious reference point for men like Kennedy. First, it was admirably suited to the rhetorical resources of popular culture. Many of Kennedy's verses, along with those of other Jacobin poets, were set to Jacobite tunes, which evoked similar themes of exile and loss. Others, such as "Skirving's Farewell to his Country", were set to popular songs dealing with these themes, in this 
case Allan Ramsay's "Farewell to Lochaber" (One of the Herd, 1794, p. 10).

Second, and more importantly, exile, following on from trial, dramatized the conflict between the state and radical reformers (Epstein, 1996, pp. 22-51; Davis, 2005, pp. 148-58). Part of what Kennedy was doing in styling himself as a "Scotch Exile" in London was joining in a critique which was being levelled against Scottish institutions by opposition Whigs as well as Paineite radicals in the 1790s. Their argument was that Scottish institutions, Scottish law in particular, were more draconian and more tyrannical than their English equivalents. The debates surrounding the sentences of transportation passed on Thomas Muir and Thomas Fyshe Palmer gave parliamentary Whigs such as Charles Fox an opportunity to denounce this evidence of "the infamous fabric of Scottish persecution", while Charles Grey claimed that "Scotland had no more liberty, than it had under the race of the Stuarts" (Parliamentary History, 1817, cols. 1300, 1563). Similarly, Kennedy suggested he was little different from those displaced by persecution and despotism elsewhere in Europe - he had fled the tyranny of Scottish law for the relative freedoms afforded by "exile" in England.

Dwelling on the theme of exile proved politically useful at different times and in different contexts. For example, in a radical movement of dwindling numbers in the mid-1790s the exile of Muir and his companions galvanized the existing membership of the reform societies and attracted new recruits (Harris, 2008, pp. 99-100; McFarland, 1994, p. 105). Later, in the period surrounding the first reform bill in the $1830 \mathrm{~s}$ and the emergence of the Chartist movement, exile was dwelt on as a characteristic crime of unreformed and arbitrary Tory government (Tyrell, 2004, pp. 25-56). This flexibility made exile a central concern to radicals.

This centrality is reflected in the historiography, which privileges those "martyrs" exiled from their country. The exiles of the 1790s, in particular, are the celebrities of the historiography, the worthy subjects of both academic and populist biographies and even operas (Bewley, 1983; Macmillan, 2004; Scottish Opera, 2004). While all histories of radicalism make much of trial and exile as transformative moments in the internal histories of their subject, even studies that have followed the "martyrs" into exile have not followed them on their return.

This essay addresses the neglected flipside of this privileged theme of "exile" and explores the idea of radical "return". There were two episodes of multiple transportations from Scotland during the period preceding the Reform Acts: first, the "Scottish Martyrs" transported in the 1790s (three of whom, of course, were not Scottish); and second, the 
nineteen men who were transported for their involvement in the abortive "general rising" of 1820 . Both of these episodes provide only a limited sample of radical returnees. Of the Scottish Martyrs of the 1790s only one returned to Britain. Of the nineteen transported after 1820, only two returned. Nevertheless, the experiences of these three men provide a useful insight into how the ideas of exile and return featured in radical political culture.

The Scottish Martyrs ${ }^{1}$ of the 1790 s were transported to Botany Bay for sentences of between seven and fourteen years for their involvement in radical politics and, in particular, their participation in a series of Conventions that met in Edinburgh between 1792 and 1794 (Pentland, 2004, pp. 340-60). Only one man returned to Britain and he was not one of those who had been born or lived in Scotland. Maurice Margarot had played a prominent role as chairman of the radical London Corresponding Society, formed in 1792. He was selected as one of the Society's delegates to attend the British Convention in Edinburgh, which sat between November and December 1793 before it was dispersed by the authorities and its leadership (including Margarot himself) arrested. Margarot had flamboyantly arrived at the High Court of Justiciary for his trial dressed as a French Revolutionary and walking underneath a triumphal arch of a "liberty tree" in the shape of an "M" (Cockburn, 1888, II, p. 23-4). He was deliberately confrontational throughout his trial and carried this into his experience of exile. In New South Wales, Margarot quickly gained a reputation as a trouble maker. When, for example, Joseph Holt, a prominent United Irishman exiled after the rising of 1798, arrived in the colony it was to Margarot's house that he was first invited. The following morning, Holt was warned by Captain Johnstone that "you lodged in the most seditious house in the colony" (Memoirs, 1838, II, p. 73).

On his return from exile in the middle of 1810 Margarot re-engaged with radical politics (Roe, 1958, pp. 75-6). He was afforded an opportunity to give evidence to the select committee on Transportation and denounced a system of corruption and arbitrary punishment, peculation and monopoly in the stores (Report, 1812, pp. 52-5). 1812 seems to have been the turning point, at which Margarot's activities took on something of their old character and he became, once again, a figure of considerable interest to those in authority. This was a year of profound crisis

1. The Scottish Martyrs are usually seen as being comprised of five men: Thomas Muir, Thomas Fyshe Palmer, Joseph Gerrald, William Skirving, and Maurice Margarot. Sometimes George Mealmaker (tried and transported in 1798) and Robert Watt (executed in 1794) are also included. 
in the British state, which was suffering from a severe recession caused by the dual impact of the Orders in Council and Napoleon's blockade, while government was faced with the escalating disruption associated with Luddism and the aftermath of the only assassination of a British Prime Minister.

Margarot chose this moment to throw himself back into politics with two pamphlets: Thoughts on Revolution and Proposal for a Grand National Fubilee. Both demonstrated that his radical sentiments remained undimmed. The latter developed the idea of a redistributive jubilee. This was a biblical concept with a key role in the metropolitan ultraradicalism of the followers of Thomas Spence, and has been characterized as involving a kind of parish-based communism (Chase, 1990, pp. 138-40). Margarot's experience of exile in Australia, where radical land schemes might be seen as applicable, may well have moved him closer to the position held by Spence's supporters. Finally, this one-time exile was not afraid to risk imprisonment again, apparently travelling to France to attempt to encourage Napoleon to invade England and restore the Saxon constitution (Prothero, 1981, p. 89).

Of most interest for this essay, however, is the fact that Margarot made two kinds of return to Scotland between 1811 and 1812. The first involved revisiting his experiences in Scotland. He had returned from exile in penury and part of his activity was a desperate scrabble to make ends meet. At the same time he sought to maintain a rhetoric of manly "independence" for his radical colleagues. He expressed this in a letter to one of them declaring that "I would rather fall with such than live to associate with public Depredation \& partake of the public plunder" (HO102/22, f. 533, Maurice Margarot to Arthur Kidder, 26 Nov. 1812). He made these claims in spite of a quite extraordinary letter he addressed to Henry Dundas, first Viscount Melville, the bête noire of Scottish radicals, on 23 May 1811. Margarot had intended to send it but, in the covering letter to Melville's son and heir, he made it clear that he had been rudely interrupted by the death of Lord Melville on 27 May. The letter itself is one of the most brazen of the many begging letters in the Melville papers. It offered Melville, on his death bed, a unique opportunity to atone for his sins in having had Margarot transported:

Your Lordship may now avail yourself of that timely repentance \& in some measure attone $[$ sic $]$ for your unjust persecution of an individual unknown \& unoffending [...] seize the opportunity my Lord. Let not the Grave enclose you unrepenting or me unredressed - the Vanities of the World now recede both from your Eyes \& from mine-futurity open[s] to our view-worldly grandeur falls upon the sense \& a just judgement from an all discerning Judge 
is at hand - you my Enemy I admonish — be my Enemy no more-you my unjust persecutor redress a part of my wrongs. (GD51/6/1782, ff. 1-2.)

The unrepentant radical asked his persecutors to repent on his return. It does not appear from the papers that any compensation was forthcoming.

The following year, however, Margarot physically returned to Scotland, where he was watched and followed very carefully. There was a flurry of activity to try to get an accurate description of him into circulation. And because he was watched so closely, the returned exile affords the historian glimpses of tenacious radical networks it would otherwise be very difficult to identify. So, for example, in Paisley Margarot dined with Archibald Hastie, a baker who had been a delegate to the British convention in 1793 and was the leader of Paisley radicalism for decades (HO102/22, f. 629, John Connell to Lord Sidmouth, 22 Dec. 1812). In Edinburgh one of his contacts was the solicitor William Moffat, a friend of Thomas Muir, who had fled Edinburgh following the suppression of the Convention (Harris, 2008, p. 162). Other contacts, stated the Lord Advocate, "were known to me formerly when I was an active Member of the Committee of the Goldsmiths Hall Association which was formed for supporting the Constitution in December 1792" (HO102/22, f. 556, Archibald Colquhoun to Sidmouth, 2 Dec. 1812). Glearly, Margarot could still rely on the support of radical connections made in the 1790s and apparently reported to his associates in London that: "He found the good old conventional \& Republican Party in that part of the Kingdom [Scotland] to be as determined as ever" (HO102/22, f. 537, Sidmouth to Colquhoun, 27 Nov. 1812).

Of more concern for the authorities was exactly what Margarot was doing in Scotland. He was, apparently, unguarded and injudicious in his language. It was reported that "his conversation when he first came from Carlisle in the Stage Coach was open \& violent, in censuring every thing here \& in praising Bonaparte even for the murder of Captain Wright" (HO102/22, f. 525, Colquhoun to Sidmouth, 22 Nov. 1812). There was concern that Margarot, who had also been touring the disturbed north of England, was attempting to politicize the massive weavers' strike of 1812. And he was certainly working at the publication of his two pamphlets (HO102/22, ff. 455, 509, Colquhoun to Sidmouth, 4 and 15 Nov. 1812). What comes across from the authorities is a sense of panic that this returnee was acting as that bogey of febrile loyalist imaginations, the radical emissary, sent out from London to "poison the minds of the lower orders". The Home Secretary was certainly concerned that "there are at this time in Scotland materials for this Man \& his associates to 
work upon, which are highly favourable to their malignant designs" (HO102/22, f. 537, Sidmouth to Colquhoun, 27 Nov. 1812).

From the point of view of the history of radicalism, the most interesting and the most plausible explanation is the one forwarded by John Connell, the Sheriff of Renfrewshire, following the interrogation of those with whom Margarot had associated and the examination of their papers. He suggested that Margarot was an integral part of Major Cartwright's attempts to reorient and revive the parliamentary reform movement in 1812, through the circulation of printed petitions and the establishment of Hampden clubs. Several of those who Margarot contacted had letters from Cartwright in their possession (HO102/22, ff. 629, 648, Connell to Sidmouth, 22 and 25 Dec. 1812). And Margarot was the obvious choice for this kind of endeavour. The returned exile, the victim of persecution, was the perfect vehicle with which to attempt to revitalize the reform movement. It is likely that those radicals who were visited by Margarot were also those who offered hospitality to Major Cartwright himself on his proselytizing tour three years later in 1815, an event typically seen as kickstarting postwar Scottish radicalism (Roach, 1970, pp. 17-25; Life and Correspondence, 1826, II, pp. 110-7).

So, Margarot was a returned radical whose ardour apparently remained undimmed; who could use pre-existing contacts to tour the north of England and Scotland and provides some insight into the tenacity of these radical networks; and whose status as a returned exile proved to be politically useful. Historians know virtually nothing about radical politics in Scotland between 1800 and 1815, but the return of Margarot offers some valuable clues as to where they might look and suggests that it might be necessary to rethink the chronology of Scottish radicalism.

The life histories of the martyrs of the 1790s have been more assiduously researched than those of other transportees. They were wealthier, more literate and better connected than those men who were to follow them to Botany Bay. The abortive general rising across the west of Scotland in April 1820 had the air of a movement of desperation rather than one of aspiration. Indeed, post-war popular radicalism between 1815 and 1820 attracted a social constituency that was more monolithic than had been the case for the movement of the 1790s and the Union Societies of 1819-20 recruited heavily in the weaving communities of the central belt, Tayside and Perthshire. In the historiography of the 1820 rising itself, it is those who were "martyred" in the most obvious sense, by giving up their lives, whose names are indelibly associated with events: Andrew Hardie, John Baird and James Wilson. Besides these three, however, nineteen other men were transported for their involvement. They have 
attracted some attention - notably from the descendants of one of the men (Macfarlane, 1981). It was only in 1993, after a prolonged restoration in the 1980s, that the names of these transported men were added to the monument that had been raised in 1847 in Sighthill Cemetery in Glasgow (Ellis and Mac a'Ghobhainn, 2001, p. XI). This monument itself, and others, demonstrate that the memory of 1820 played an important role in political culture and language in the nineteenth and twentieth centuries (Pentland, 2008). The two men who came back from Botany Bay-Thomas McFarlane and Andrew White - offer useful case studies of how their own exile and returns contributed to the continuing "usability" of 1820 in radical politics.

The role of McFarlane was particularly prominent. In contradisctinction to his peers, he was not a young man even in 1820. Born in Glasgow in 1775 or 1776 he had played an active role in the radical movement of the 1790s and was residing in Condorrat at the time of the abortive general rising (Macfarlane, 1981, p. 38). He had been one of the men who had gone with Baird and Hardie to Bonnymuir and had faced and engaged the troops. He also had the dubious distinction of being one of the men seriously injured in the affray, having sustained a sabre cut across his face. He was transported to Botany Bay for his offences and, after the King granted an Absolute Pardon in 1836, he returned to Scotland in 1839 (Caledonian Mercury, 2 Dec. 1839).

What is interesting is how he was treated when he returned. On 15 January 1840 he was fêted by the Working Man's Association of Airdrie, a Chartist Society, which held its second annual soirée in his honour. The members marched out of Airdrie with a band and banners to meet McFarlane in Glenmavis. There were a number of speeches, which were reported in the press, and the public address from the Association amply demonstrated the purpose of the event. Political movements, of course, always appeal to the past as well as to the future. Parading veterans is one powerful way of achieving this appeal. The Association reminded McFarlane of his involvement in reform since the 1790s, when he had apparently swallowed a compromising piece of paper on which was written an illegal oath. Speakers dwelt, however, on his involvement at Bonnymuir, pointing out that he still bore the scar "a convincing proof of the merciful disposition of a Tory government" (Scottish Patriot, 25 Jan. 1840). Interestingly, all newspaper reports in which McFarlane featured mentioned his scar - both his physical presence and his damaged body served to dramatize the conflict on which radical rhetoric focused. Entertainment at the soirée was provided by the singing of "Dark Bonnymuir", a composition by one of McFarlane's fellow transportees, Allan Barbour Murchie, which had been published in 1820. The audience was also 
treated to a performance by the talented Misses Fraser, the daughters of another man who had been "out" in 1820, John Fraser the editor of the True Scotsman (Fraser, 1879, pp. 20-9). All told, McFarlane's reception was a consummately "1820" event and demonstrates how the memory of the rising was being used within radical political culture.

This was not the end of McFarlane's involvement in radical politics. 1841 saw an enormous gathering of Chartists in Glasgow to meet Fergus O'Connor, who was visiting the city. "Macfarlane of Condorrat, the aged Bonnymuir martyr" was given pride of place at the table in the evening sitting alongside O'Connor and was presented with "a handsome ebony staff, silver-mounted, and a sovereign to pay his travel expenses" (Northern Star, 16 Oct. 1841). McFarlane's presence helped to emphasize a central theme of the rest of O'Connor's visit, during which opportunities were taken not only to mention and draw comparisons with the 1820 rising but physically to escort O'Connor to the sites and relics associated with it. In Stirling, he was taken to the Castle and shown where Baird and Hardie had been executed; he was taken to the dungeon where the prisoners had been held; and he was shown the pikes used by the Radicals, which were held in the armoury (Northern Star, 6 Nov. 1841).

In this way, the return of McFarlane allowed Chartists both to confirm the "Radical War" as a foundational moment and to draw parallels with their own conflict with the state. In newspaper reports McFarlane and earlier radicals were co-opted as the "pre-cursors of Chartism" or even more simply as "Chartists". McFarlane contributed to the continuing memory of the events of 1820 , which would see the monument raised in Sighthill in 1847. Indeed, "the venerable Macfarlane" with his "sabre wound" was a prominent guest at the dinner commemorating the anniversary of the executions and celebrating the recent erection of the monument (Glasgow Saturday Post, 11 Sept. 1847).

The memory of the events of 1819-20 could be used in different ways: to support physical force and insurrectionary violence or to justify resistance or as a warning against the dangers of physical force (Pentland, 2008, pp. 153-7). For it to be usable at all, however, required a stock of memories, images and relics on which to hang these various interpretations. A returned radical provided the perfect foil. McFarlane clearly was not much of a speaker - there are only a couple of mumbled lines of thanks recorded at dinners in his honour. He was not, however, there to speak. He was far more important as a mute physical relic of the rising, his scar and venerability making him an object to be displayed, a peg on which various interpretations could be hanged. 
As far as it is possible to ascertain, Andrew White, the other returnee, came back to no mass meeting and there were no soirées in his honour. White, who had been a mere boy of sixteen when he had appeared in arms at Bonnymuir, was a "lucky" transportee. On arrival in Australia he was made a house servant to a progressive master, Dr Douglass, who was interested in the rehabilitation rather than the punishment of convicts. He secured an absolute pardon in February 1824, fully twelve years before his peers, and returned to Britain with his master immediately (Macfarlane, 1981, p. 57-60).

$\mathrm{He}$ is harder to trace in the records, but White clearly also became an active Chartist. A very slim notice in the Northern Star reports that he addressed a crowd in the People's Hall in Birmingham in 1849 on his involvement in the rising (9 June 1849). Again, there was an obvious political purpose - amidst agitation for a pardon for transported Chartists such as John Frost, who had led the Newport rising of 1839, the political capital of transportees was high.

Perhaps the more interesting facts about White do not concern his life, but rather his death. White died in Glasgow Infirmary in November 1872 and a short notice in the Glasgow Herald recorded: "He is to be interred today in Sighthill Cemetery, and in accordance with his dying request his body will be laid in the same grave which contains the remains of Baird and Hardie" (23 Nov. 1872). There has been some dispute as to whether White is, in fact, buried alongside Baird and Hardie (Macfarlane, 1981, p. 60). The intention was, however, clear. This was to be the ultimate physical return, White having his bones mingled with those of Baird and Hardie and asking different generations to contemplate the events of 1820 .

This flow of information about the radical war, which has made its reshaping and reimagining possible, was maintained by more than the physical returns of individual transported radicals. Letters were sent back from Botany Bay, which were intended for publication and conveyed subtle political messages. Such letters, like those of other emigrants, often praised their new homes in terms which made unflattering comparisons with the Scotland from which they had been transported. William Smith, for example, was enthusiastic about the economic freedom afforded in New South Wales, where there was "no rent, no taxes, and most part of the land bears two excellent crops every year"; Andrew White could report that he was "more comfortable than when in Scotland" and both he and Thomas McGulloch included positive news about the other transportees (Copy, 1821; Copy, 1822; Caledonian Mercury, 27 Sept. 1824).

Indeed, some of the transported men deliberately sought their freedom by returning items to Scotland. Most notably, John McMillan encouraged 
the radical journalist Peter Mackenzie to pursue the campaign for their pardon by sending back items which would help him make the case. In 1834, for example, McMillan (having somehow read Mackenzie's account of the "spy system", which had brought disaster for the radicals in 1820) sent Mackenzie his journal, with a view to publication, and a pair of "Radical Boots" or shackles, presumably to help to dramatize the transportees' fate (GD185/1, f. 2, 17 Aug. 1834). McMillan, however, did not himself return to Scotland like McFarlane and White and instead he made a success of his new life in Australia. Tellingly, however, he tried to perpetuate the memory of 1820 in the colony itself. He named one of his farms "Thrushgrove", in conscious salute to Turner of Thrushgrove, who had allowed a monument to be erected to Hardie and Baird on his estate in 1832 (Manchester Times, 21 Nov. 1840).

In looking at these few men who did return to Scotland from political exile, it would be difficult to draw any profound conclusions from such a small sample. Exile and return as a theme does, however, speak to two historiographical currents within the study of popular politics. First, the work of James Epstein, Iain McCalman and others has vastly expanded our perceptions of what constitutes the "political" and has encouraged historians to study symbolic practices and what might broadly be called the political culture of popular movements. Exile played an important role in shaping radical culture and examining the activities of returned exiles provides one way of looking at this. In particular, the historicity of popular politics - the ways in which radicals looked to the past to create political identities and push agendas in the present - is highlighted by the experiences of these returnees.

Secondly, scholars are increasingly examining various themes within a wider "British world" rather than within narrowly defined national boundaries. There have been recent and convincing calls to "globalize the age of reform". Achieving this would involve not only waving goodbye to exiles as they exit one national historiography and enter another, but also following men such as Margarot, McFarlane and White into exile and exploring those roles they played within popular politics on their return. 


\section{Bibliography}

\section{Manuscript sources}

National Archives of Scotland, Edinburgh, Melville Castle Papers, GD51/ 6/1782.

National Archives, London, Home Office Correspondence (Scotland), $\mathrm{HO} 102 / 22$.

William Patrick Library, Kirkintilloch, Peter Mackenzie Papers, GD185/1.

\section{Newspapers}

Caledonian Mercury.

Glasgow Evening Post.

Glasgow Herald.

Manchester Times.

Northern Star.

Scottish Patriot.

\section{Printed}

A Scotch Exile [James Kennedy], Treason! or Not Treason! Alias the Weavers Budget, London, 1795.

Bewley Christina, Muir of Huntershill, Oxford, Oxford University Press, 1983.

Chase Malcolm, "From Millennium to Anniversary: The Concept of Jubilee in Late Eighteenth- and Nineteenth Century England", Past E Present, no. 129, Nov. 1990, pp. 132-47.

Cockburn Henry, An Examination of the Trials for Sedition which have hitherto Occurred in Scotland, Edinburgh, 2 vols, 1888.

Copy of a Very Interesting Letter from Botany Bay, Glasgow, 1821.

Copy of a Very interesting Letter which was received in Glasgow on Wednesday last from Andrew White, Glasgow, 1822.

Davis Michael T., "Prosecution and Radical Discourse during the 1790s: The Case of the Scottish Sedition Trials", International Fournal of the Sociology of Law, vol. 33, no. 3, September 2005, pp. 148-58.

Ellis Peter Berresford and Mac A'Ghobhainn Seumas, The Scottish Insurrection of 1820, Edinburgh, John Donald, revised edition, 2001.

Epstein James, "'Our Real Constitution': Trial Defence and Radical Memory in the Age of Revolution", Re-reading the Constitution: New Narratives in the Political History of England's Long Nineteenth Century, James Vernon (ed.), Cambridge, Cambridge University Press, 1996, pp. 22-51.

Fraser James Roy, Memoir of John Fraser, Newfield, Fohnstone, Paisley, 1879. 
Harris Bob, The Scottish People and the French Revolution, London, Pickering \& Chatto, 2008.

Life and Correspondence of Major Cartwright, F. D. Cartwright (ed.), London, 2 vols, 1826.

MaFarland E. W., Ireland and Scotland in the Age of Revolution, Edinburgh, Edinburgh University Press, 1994.

MacFarlane Margaret and Alastair, The Scottish Radicals Tried and Transported for Treason in 1820, Stevenage, Spa Books, 1981.

MacMillan Hector, Handful of Rogues: Thomas Muir's Enemies of the People, Glendaruel, Argyll Publishing, 2005.

Memoirs of Joseph Holt, General of the Irish Rebels, in 1798, T. Crofton Croker (ed.), London, 2 vols, 1838.

One of the Herd, Husks for Swine: Dedicated to the swine of England, the rabble of Scotland, and the wretches of Ireland, Edinburgh, 1794.

The Parliamentary History of England, from the earliest period to the year 1803, William Cobbett (ed.), London, T. C. Hansard, 1817, vol. 30.

Pentland Gordon, "Patriotism, Universalism and the Scottish Conventions, 1792-94", History, vol. 89, no. 295, July 2004, pp. 340-60.

_, "Betrayed by infamous spies'? The Commemoration of Scotland's 'Radical War' of 1820", Past and Present, no. 201, November 2008, pp. 141-73.

Prothero Iowerth, Artisans and Politics in Early Nineteenth-Century London: John Gast and his Times, London, Methuen, 1981.

Report from the Select Committee on Transportation, London, HMSO, 1812.

Roe Michael, "Maurice Margarot: A Radical in Two Hemispheres, 1792-1815", Bulletin of the Institute of Historical Research, vol. 31, no. 83, May 1958, pp. 68-78.

Scottish Opera, Friend of the People: An Opera in Three Acts with a Prologue, London, Boosey \& Hawkes, 2004.

Tyrell Alex and Davis Michael T., "Bearding the Tories: The Commemoration of the Scottish Political Martyrs of 1793-94", Contested Sites: Commemoration, Memorial and Popular Politics in Nineteenth-Century Britain, Alex Tyrell and Paul A. Pickering (eds), Aldershot, Ashgate, 2004, pp. 25-56. 